\title{
The Rodeo de la Bordalesa Tonalite Dykes as a Lower Devonian Magmatic Event: Geochemical and Isotopic Age Constraints
}

\author{
Carlos A. Cingolani, Eduardo Jorge Llambías, Miguel A.S. Basei, \\ Norberto Javier Uriz, Farid Chemale Jr. and Paulina Abre
}

\begin{abstract}
One of the 'pre-Carboniferous units' from the San Rafael Block is the sedimentary Río Seco de los Castaños Formation, which is distributed in isolated outcrops within the Block. At the Rodeo de la Bordalesa area two small intrusives in the mentioned unit were mapped, composed of tonalitic rocks, lamprophyre ('spessartite-kersantite') and aplite dykes. We present in this paper, geochemical and isotopic data from the gray tonalitic rocks with abundant mafic enclaves and late magmatic aplite veins. The country rocks are a folded sequence of feldspathic sandstones, wackes, and shales. The Rodeo de la Bordalesa tonalite dykes are characterized by high to medium potassium concentration, with metaluminous composition and I-type calc-alkaline signature. The $401 \pm 4 \mathrm{Ma} \mathrm{U}-\mathrm{Pb}$ zircon age corresponds to the emplacement time and it is confirmed by the $\mathrm{K}-\mathrm{Ar}$ biotite age.
\end{abstract}

C.A. Cingolani $(\bowtie) \cdot$ E.J. Llambías

Centro de Investigaciones Geológicas, Universidad Nacional de La Plata, Diag. 113 n. 275,

CP1904 La Plata, Argentina

e-mail: carloscingolani@yahoo.com

E.J. Llambías

e-mail: 1lambias@cig.museo.unlp.edu.ar

M.A.S. Basei

Centro de Pesquisas Geocronológicas (CPGeo), Universidade de São Paulo, São Paulo,

Brazil

e-mail: baseimas@usp.br

C.A. Cingolani · N.J. Uriz

División Geología, Museo de La Plata, UNLP, Paseo del Bosque s/n, B1900FWA La Plata, Argentina

e-mail:norjuz@gmail.com

F. Chemale Jr.

Programa de Pós-Graduação em Geologia, Universidade do Vale do Rio dos Sinos,

93.022-000 São Leopoldo, RS, Brazil

e-mail: faridcj@unisinos.br; faridchemale@gmail.com

P. Abre

Centro Universitario Regional Este, Universidad de la República, Ruta 8 Km 282, Treinta y

Tres, Uruguay

e-mail: paulinabre@yahoo.com.ar

C.A. Cingolani (ed.), Pre-Carboniferous Evolution of the San Rafael Block, 
The $\mathrm{Rb}-\mathrm{Sr}$ whole rocks and biotite age of $374 \pm 4$ Ma could be related to deformation during the 'Chanic' tectonic phase. Nd model ages $\left(\mathrm{T}_{\mathrm{DM}}\right)$ show an interval between 1 and $1.6 \mathrm{Ga}$, indicating Mesoproterozoic age derivation, whereas the negative $\varepsilon_{\mathrm{Nd}}$ is typical from crustal sources. The crystallization age for the Rodeo de la Bordalesa tonalite corresponds to a Lower Devonian time and suggests that part of the Late Famatinian magmatic event is present in the San Rafael Block. The dykes are contemporaneous with the large peraluminous batholith in Pampeanas Ranges, with the transpressional shear belts during 'Achalian' event and could be correlated with the Devonian magmatism present in the southern part of the Frontal Cordillera. The geochemical and geochronological data allow us to differentiate the Rodeo de la Bordalesa tonalite from the mafic rocks exposed at the El Nihuil area.

Keywords San Rafael Block • Tonalite dykes • Geochronology • Lower Devonian - Magmatic event

\section{Introduction}

The San Rafael Block (SRB) lies in west-central Mendoza province, Argentine $\left(35^{\circ}\right.$ S-68 $30^{\prime} \mathrm{W}$ ), and has SSE-NNW structural Cenozoic trend in the pre-Andean region. To the North and South the Cuyo and Neuquén sedimentary basins bound it, respectively. To the East the SRB passes into the Pampean plains vanishing under the modern basaltic back arc volcanism and sedimentary cover; the boundary to the West is defined by the Andean foothill (Fig. 1). Paleontological and geological

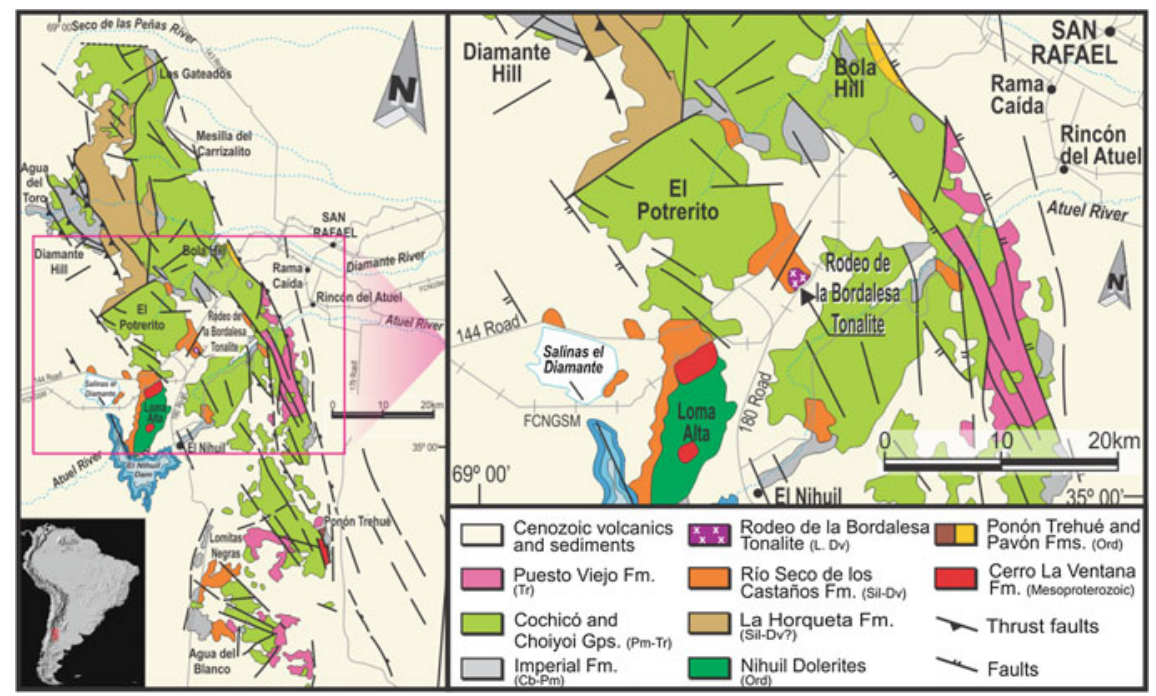

Fig. 1 Regional geological sketch map of the San Rafael Block and location of the Rodeo de la Bordalesa study region 
evidence allow interpreting the SRB as a southern extension of the Cuyania terrane (Ramos 2004 and references there in). Diverse igneous-metamorphic and sedimentary units of Precambrian to Middle Paleozoic age are present and are known as 'pre-Carboniferous units' since they are located below the Upper Paleozoic regional unconformity (Dessanti 1956).

One of these units is the sedimentary Río Seco de los Castaños Formation, which is distributed in isolated outcrops within the SRB (Fig. 1). At the Rodeo de la Bordalesa area, Dessanti (1956) mapped two small intrusives composed of tonalitic rocks, lamprophyre ('spessartite-kersantite'), and aplite dykes.

We present here, geochemical and isotopic data from Rodeo de la Bordalesa tonalite intrusive rocks that contribute to characterize and constrain the emplacement of these magmatic rocks, as well as to the knowledge of the correlation of the Late Famatinian event in western Argentina. The sample locations are shown in Fig. 2.

\section{Geological Background}

The Rodeo de la Bordalesa tonalite was first described as intruded in the 'La Horqueta Series' by Dessanti (1956) and mentioned by Davicino and Sabalúa (1990) as tonalite dikes ('trondjhemites') emplaced in La Horqueta sequence. After González Díaz (1964, 1981), Cuerda and Cingolani (1998) and Cingolani et al. (2003) works, the area was remapped and tonalites host rocks were assigned to the Río Seco de los Castaños Formation (Manassero et al. 2009; Cingolani et al. 2011, this volume). The Río Seco de los Castaños Formation (RSC) outcrops at (Fig. 1): a. Road 144-Rodeo de la Bordalesa: locations, where Rubinstein (1997) found Silurian acritarchs and other microfossils, and trace fossils were mentioned by several authors (Criado Roqué and Ibáñez 1979; Poiré et al. 1998; Pazos et al. 2015). Cingolani et al. (2003) as preliminary work, constraints the isotopic age and composition of the tonalitic intrusive body; b. Atuel River creek: this is the type section of the sequence, near Valle Grande area (González Díaz 1964). The beds are folded and show dipping of $50^{\circ}-72^{\circ}$ to the SE or NE. c. El Nihuil area: comprise a sedimentary sequence close to the Mesoproterozoic basement and to the Ordovician mafic rocks called 'El Nihuil Mafic Unit' (Cingolani et al. 2003). d. Lomitas Negras and Agua del Blanco areas: comprise the southern outcrops of RSC, where Di Persia (1972) mentioned a coral (Pleurodyctium) of Devonian age and conglomerates with limestone clasts bearing Ordovician fossils.

The Rodeo de la Bordalesa intrusive rock crops out near the deactivated railroad tracks ('Ferrocarril General San Martín'), as a gray tonalitic body with abundant mafic enclaves (less than $30 \mathrm{~cm}$ ) and comprising $10-30 \mathrm{~cm}$ thick late magmatic aplite veins (Fig. 2a-d). At this area the RSC is a folded sequence of feldspathic sandstones, wackes, and shales (Cingolani et al. 2003; Manassero et al. 2009). 

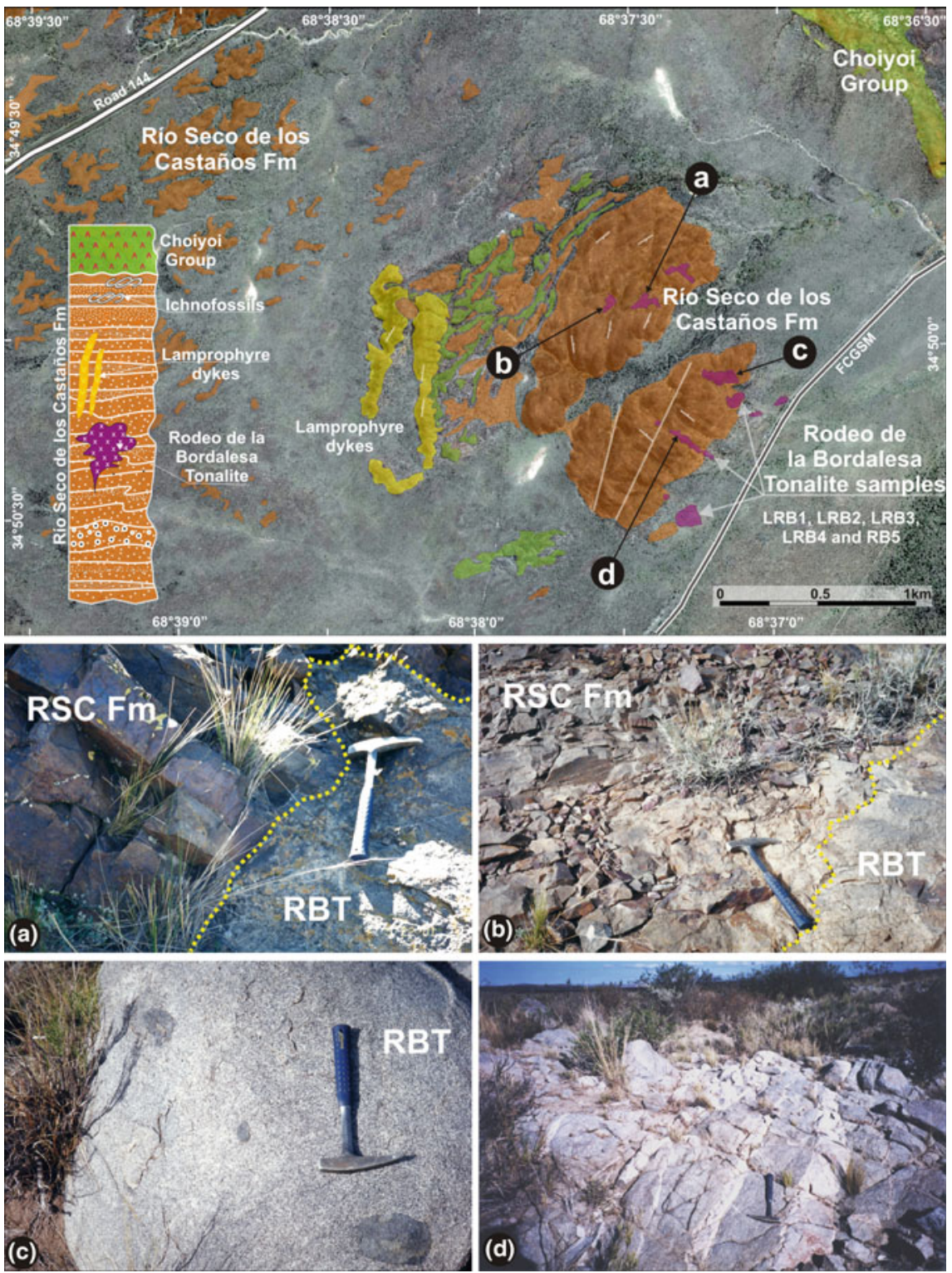

Fig. 2 Image showing the geological sketch map with stratigraphic column of Rodeo de la Bordalesa region. a, c Intrusive field relationship between the tonalite (RBT) and Río Seco de los Castaños Formation (RSC). b Inclusions in the tonalite. d The tonalite rocks intruded by aplite veins. FCGSM: railroad tracks 
Previous geochronological data yielded biotite K-Ar ages of $475 \pm 17 \mathrm{Ma}$ and 452 土 8 Ma (González 1971; González Díaz 1981) for the intrusive rocks, which are in disagreement with the intrusive character into Silurian-Lower Devonian country rocks.

\section{Petrography and Geochemistry Aspects}

The Rodeo de la Bordalesa tonalite consists of small laminar bodies intruded into the RSC unit; these intrusives are either parallel or crosscut the stratification, and although their composition is similar, they have different textures. The largest one (ca. $70 \mathrm{~m}$ thick) is close to the old railroad tracks and its country rocks (feldspathic sandstones, wackes and shales) develop a metamorphic contact characterized by recrystallized biotite and minor muscovite (Fig. 3). The tonalite shows a medium-grained equigranular texture and it is composed of zoned plagioclase (average $\mathrm{An}_{40}$ ), green amphibole (sometimes with a core of clinopyroxene), biotite, and interstitial quartz. Zircon and apatite are present as accessory minerals (Fig. 4). The other body also intrudes the RSC and crops out northward of the previously described; it consists of dykes and small irregular bodies of porphyritic tonalite. Phenocrysts consist of zoned plagioclase (average $\mathrm{An}_{50}$ ), scarce clinopyroxene surrounded by amphibole and biotite. The groundmass is composed of plagioclase, scarce biotite, and interstitial quartz.

Five samples (Table 1) were analyzed for major, trace and rare earth elements (ACTLABS, Canada). They plot in the TAS diagram adapted to plutonic rocks by Bellieni et al. (1995) into the field of tonalites (Fig. 5).

Modal composition indicates an I-type signature and in the AFM diagram (Irvine and Baragar 1971) samples show a calc-alkaline trend (Fig. 6a). They are characterized by high to medium potassium concentrations (after Peccerillo and Taylor 1976); with A/CNK index ranging from 0.90 to 0.95 they are regarded as metaluminous rocks (Fig. 6b).

The extended multielement diagram normalized to primitive mantle (Taylor and McLennan 1985) show depression of $\mathrm{Nb}$ and $\mathrm{Ti}$ and low enrichment of HFSE, typical of calc-alkaline series (Fig. 7a). The REE patterns show LREE enrichment and flat HREE behavior, also characteristic of calc-alkaline rocks (Fig. 7b).

To constrain the tectonic environment of emplacement three discrimination diagrams were applied (Fig. 8), from which it is deduced that the tonalites intruded within an active continental margin since they plot in the field of volcanic arc granitoids (Fig. 8a) from Pearce et al. (1984), while in the Whalen et al. (1987) diagram plot into the I-type field (Fig. 8b). Furthermore, Harris et al. (1986) diagram allows the discrimination of pre-collisional calc-alkaline arc-related granitoids from syn- to post-collisional intrusions and within plate intrusions. In this regard, the late- and post-collisional character of samples from the Rodeo de la Bordalesa (Fig. 8c) agree well with an emplacement within the RSC folded sedimentary rocks afterwards the 'Chanic' tectonic phase. 


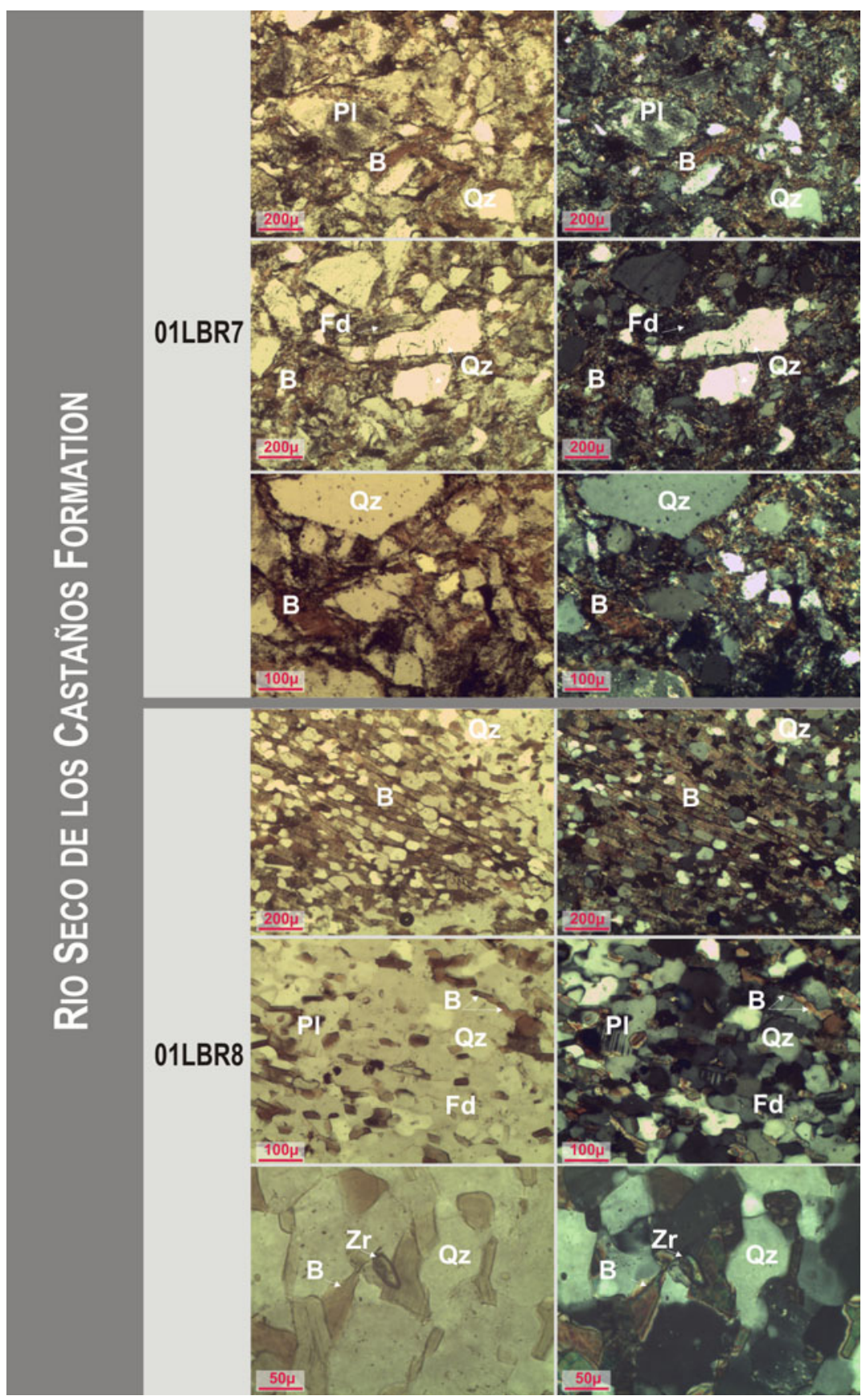

Fig. 3 Representative photomicrographs of the RSC hornfels at the contact with the tonalite rocks. $P l$ plagioclase; $Q z$ quartz; $F d$ K-feldspar; $B$ biotite. $Z r$ zircon. The abundance of recrystallized biotite is evident 


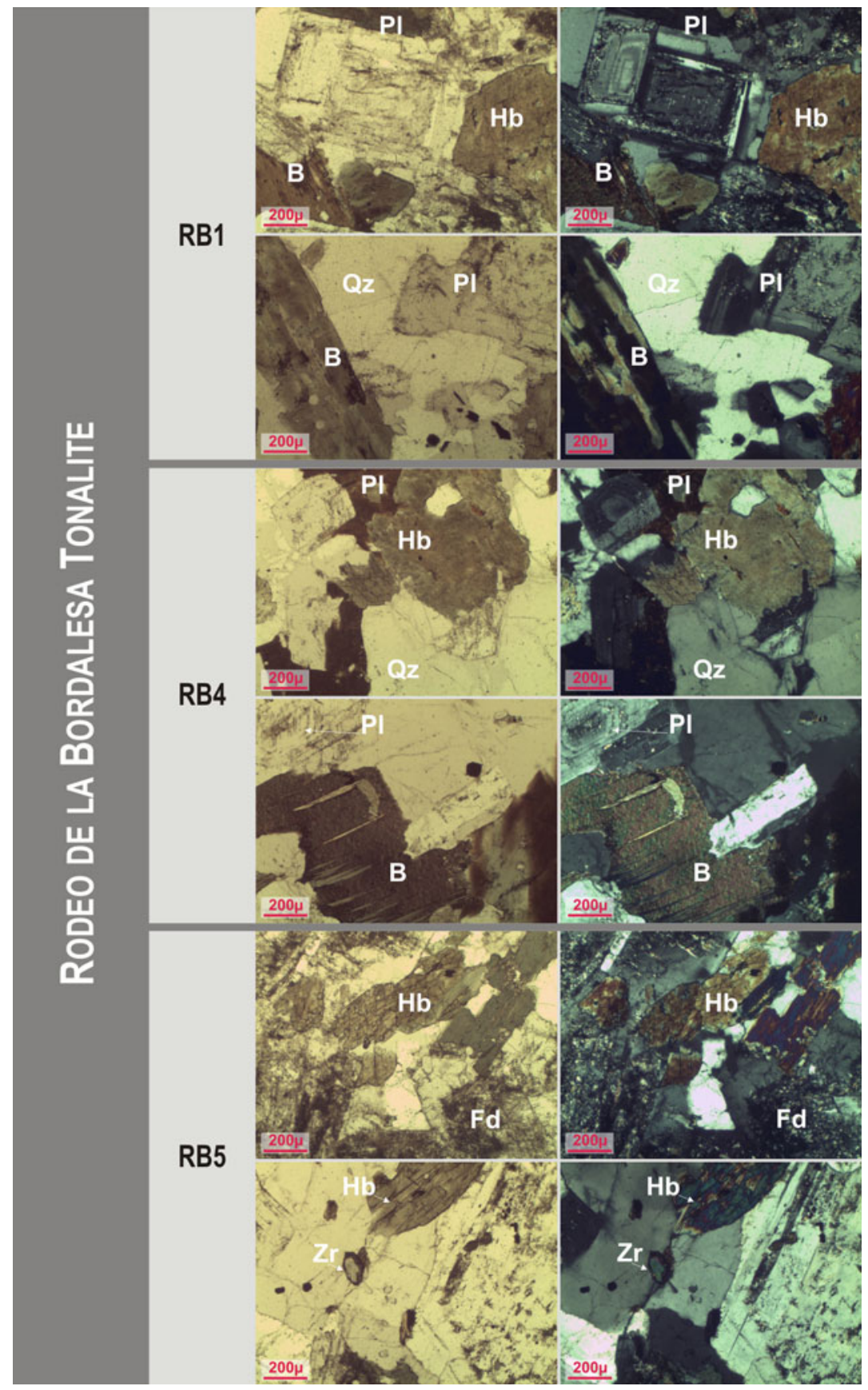

Fig. 4 Photomicrographs of the Rodeo de la Bordalesa tonalite samples showing equigranular texture. $P l$ zoned plagioclase; $H b$ hornblende; $Q z$ quartz; $F d$ K-feldspar; $B$ biotite, $Z r$ zircon 


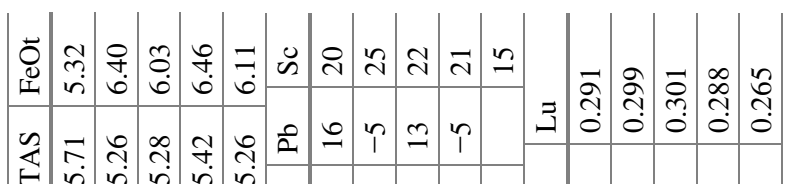

产

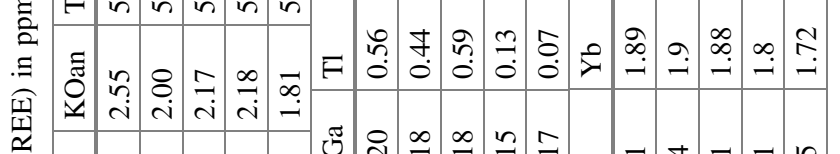

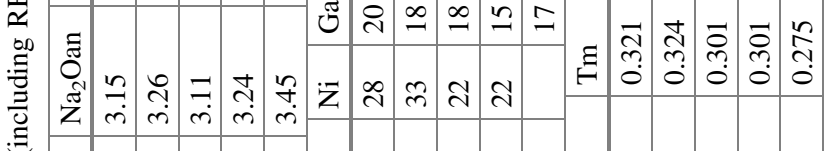

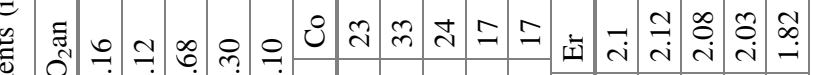
in in in $i$

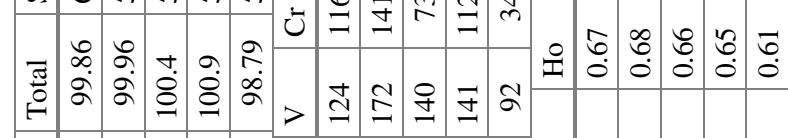

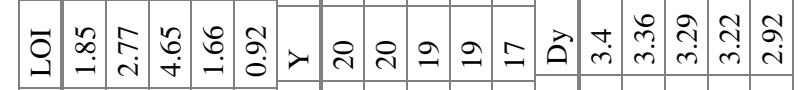

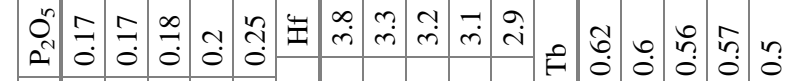

员

这

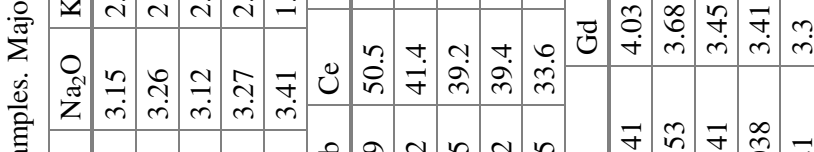

:

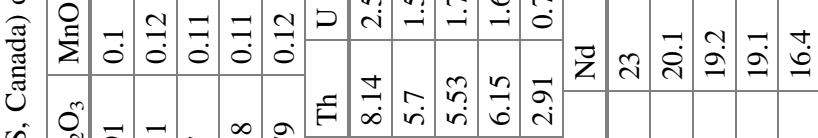

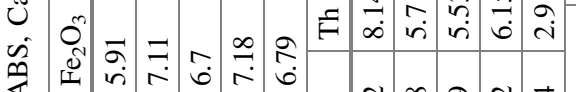

U

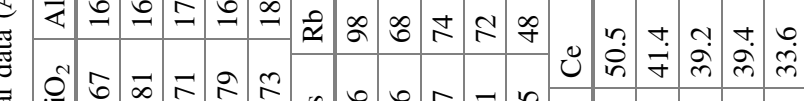

تే

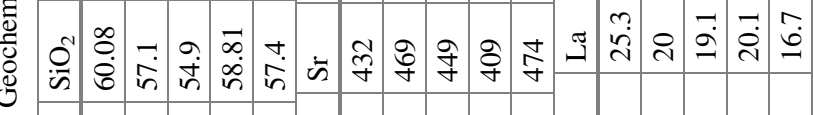

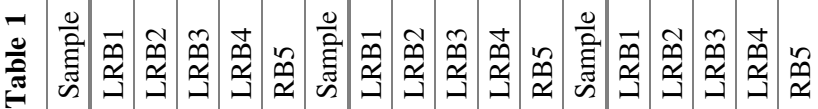




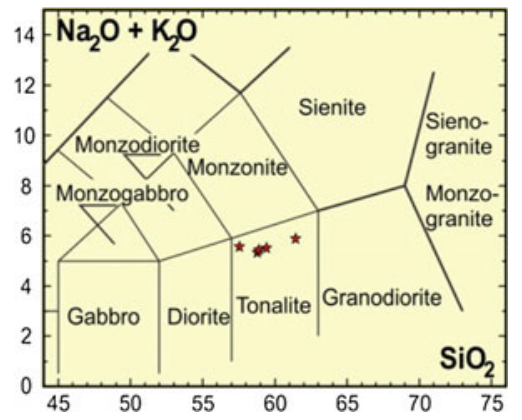

Fig. 5 TAS diagram modified by Bellieni et al. (1995)
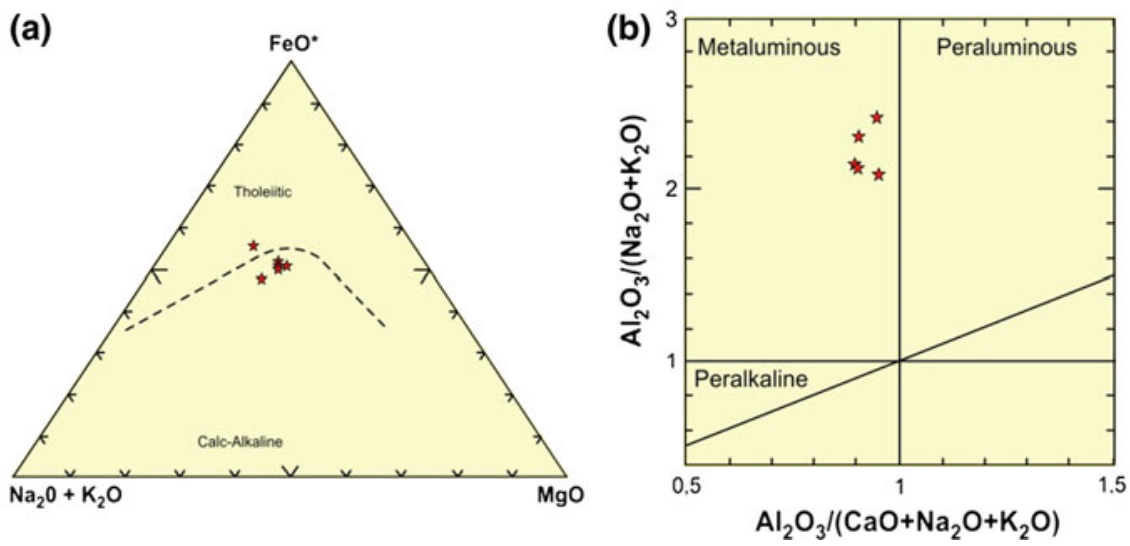

Fig. 6 a Ternary AFM diagram. b A/CNK discrimination diagram after Maniar and Piccoli (1989)

(a)

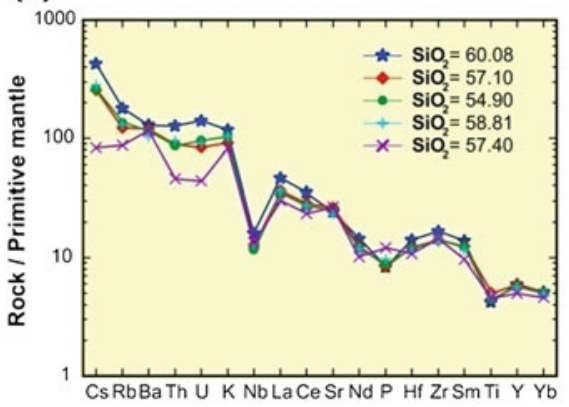

(b)

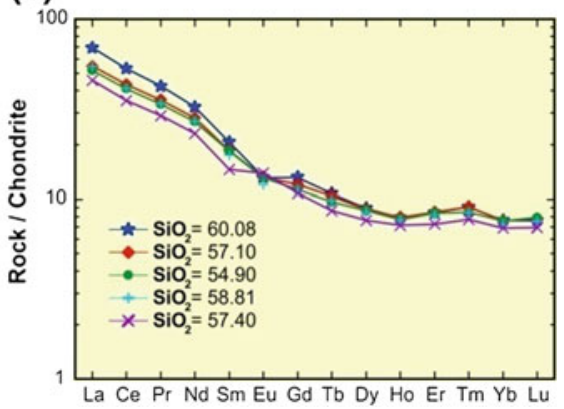

Fig. 7 a Multielements spider-diagram normalized to primitive mantle. $\mathrm{SiO}_{2}$ content of each sample is shown. b Chondrite normalized REE diagram for the five samples 
(a)

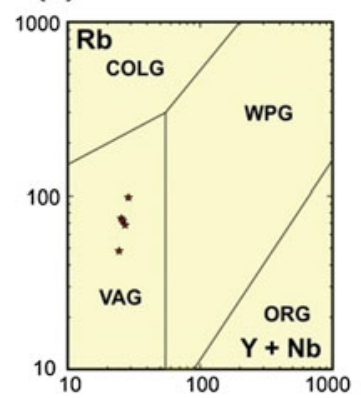

(b)

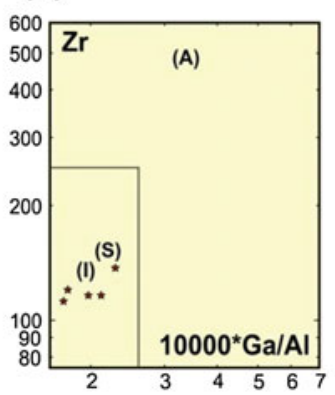

(c)

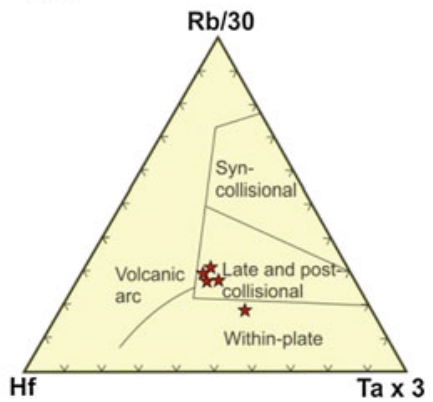

Fig. 8 Tectonic discrimination diagram of granitoids. a Pearce et al. (1984) diagram; COLG: collisional, WPG: within plate, VAG: volcanic arc, ORG: orogenic granitoids. b Whalen et al. (1987) diagram. c Harris et al. (1986) ternary diagram

All these characteristics allowed us to differentiate the Rodeo de la Bordalesa tonalite from the tholeiitic mafic rocks (mainly gabbros, amphibolites and porphyritic dolerites) exposed at the El Nihuil area (Cingolani et al. 2000).

\section{Isotopic Data}

To constrain the age of the Rodeo de la Bordalesa intrusive rocks new $\mathrm{U}-\mathrm{Pb}, \mathrm{K}-\mathrm{Ar}$, $\mathrm{Rb}-\mathrm{Sr}$ and $\mathrm{Sm}-\mathrm{Nd}$ data have been obtained, in addition to the Ordovician biotite K-Ar dates reported by González (1971) and González Díaz (1981) and Middle Devonian age (whole rock $380 \pm 20 \mathrm{Ma}$ ) by Linares et al. (1987).

a. U-Pb (ID-TIMS): The procedure for U-Pb zircon analyses at Centro de Pesquisas Geocronológicas, Instituto de Geociencias, USP (Brazil) is as follow: After $10 \mathrm{~kg}$ of sample were crushed and reduced to 140-200-mesh grain-sizes the portion rich in heavy minerals was treated with bromoform $\left(d=2.89 \mathrm{~g} / \mathrm{cm}^{3}\right)$ and methyl iodide $(d=3.3$ $\mathrm{g} / \mathrm{cm}^{3}$ ), and the fraction containing the heavy minerals was processed in the Frantz separator at $1.5 \mathrm{~A}$ and split in several zircon-rich magnetic fractions. The final purification of each fraction was done by handpicking. The dissolution of the zircon crystals was carried out with $\mathrm{HF}$ and $\mathrm{HNO}_{3}$ in Teflon micro bombs in which a mixed ${ }^{205} \mathrm{~Pb}{ }^{235} \mathrm{U}$ spike was added. A set of 15 micro bombs arranged in a metal jacket is left for three days in a stove at $200{ }^{\circ} \mathrm{C}$. Then, the $\mathrm{HF}$ is evaporated and $\mathrm{HCl}(6 \mathrm{~N})$ added to the micro bombs, replaced in the stove for $24 \mathrm{~h}$. After the evaporation of $\mathrm{HCl} 6 \mathrm{~N}$, the residue is dissolved in $\mathrm{HCl}(3 \mathrm{~N})$. $\mathrm{U}$ and $\mathrm{Pb}$ are concentrated and purified by passing the solution in an anionic exchange resin column. The solution enriched in $\mathrm{U}$ and $\mathrm{Pb}$ is, after addition of phosphoric acid, evaporated until the formation of a microdrop. The sample is deposited in a rhenium filament and the isotopic composition is determined with Finnigan MAT 262 solid source mass spectrometer. After reduction of the data (PBDAT), the results (Table 2) are plotted in appropriate diagrams using the software ISOPLOT/EX (Ludwig 1999, 2001). 


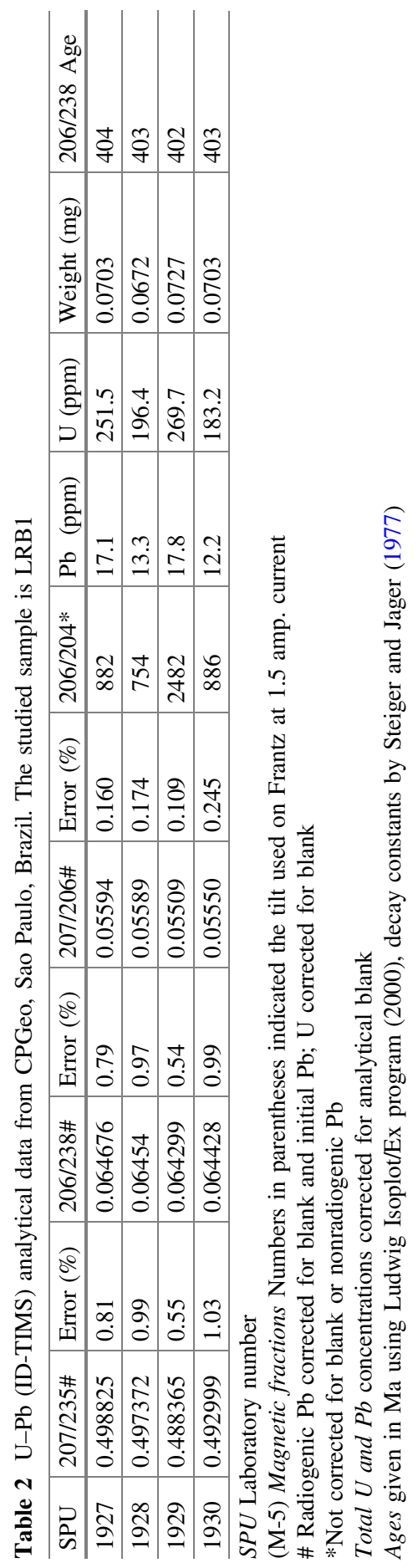




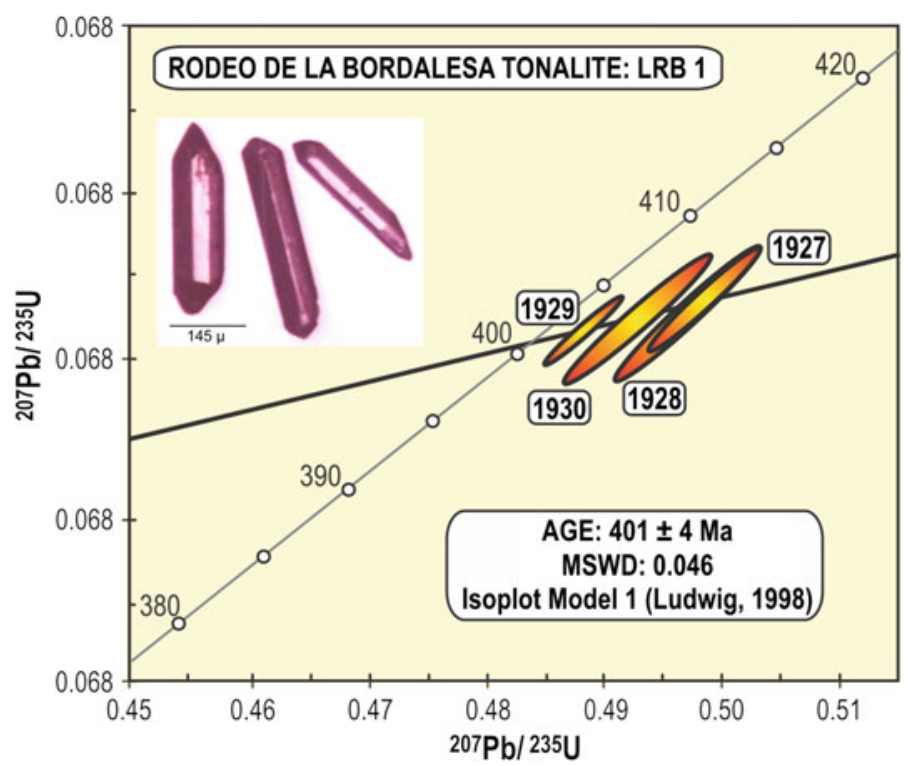

Fig. 9 U-Pb Concordia diagram. The inset show photographs under microscope of some dated zircon crystals with $300-450 \mu$ size

Table 3 K-Ar analytical data from CPGeo, São Paulo, Brazil

\begin{tabular}{l|l|l|l|l|l|l|l|l|l}
\hline $\begin{array}{l}\text { Lab } \\
\text { No } \\
\text { SPK }\end{array}$ & Field No. & Mineral & $\begin{array}{l}\text { Rock } \\
\text { type }\end{array}$ & K (\%) & Error (\%) & ${ }^{40}$ ArRad & ${ }^{40}$ ArAtm (\%) & Age (Ma) & Error (Ma) \\
\hline 7731 & RB-04A21 & Biotite & Tonalite & 6.2488 & 3.0413 & 108.95 & 6.24 & 401.30 & 17.10 \\
\hline
\end{tabular}

As we can see on the Concordia diagram (Fig. 9) the U-Pb average age obtained in four zircon fractions by ID-TIMS is $401 \pm 4 \mathrm{Ma}$ and that corresponds to Early Devonian (Emsian) time (IUGS International Stratigraphic Chart 2015).

b. K-Ar: Biotite fresh minerals were separated from one tonalite sample (RB-04) and dated using the $\mathrm{K}-\mathrm{Ar}$ methodology at the Centro de Pesquisas Geocronológicas, Instituto de Geociencias, USP (Brazil), and the duplicate obtained data are presented in Table 3. The biotite gave an age of $401 \pm 17$ Ma. This value is very close and confirms the zircon U-Pb (ID-TIMS) age.

c. Rb-Sr: The Rb-Sr method was applied using five whole rock samples from the main tonalite outcrop near de railroad tracks. The biotite separate from one whole rock was also used. $\mathrm{Rb}$ and $\mathrm{Sr} \mathrm{XRF}$ analyses as well as the mass spectrometry for $\mathrm{Sr}$ were carried out at the Laboratorio de Geología Isotópica, Universidade Federal do Rio Grande do Sul, Porto Alegre (Brazil). The sample preparation and extraction of natural $\mathrm{Sr}$ through cation exchange columns were performed at the Centro de Investigaciones Geológicas, Universidad Nacional de 
Table $4 \mathrm{Rb}-\mathrm{Sr}$ analytical data

\begin{tabular}{l|l|l|l|l|l|l|l}
\hline Field No. & Lab. No. & $\mathrm{Rb}(\mathrm{ppm})$ & $\mathrm{Sr}(\mathrm{ppm})$ & ${ }^{87} \mathrm{Rb} /{ }^{86} \mathrm{Sr}$ & Error & ${ }^{87} \mathrm{Sr} /{ }^{86} \mathrm{Sr}$ & Error \\
\hline 01LRB1 & CIG 1248 & 52.9 & 506.6 & 0.3023 & 0.006 & 0.707074 & 0.000021 \\
\hline 01LRB2 & CIG1249 & 40.8 & 488 & 0.242 & 0.0048 & 0.706387 & 0.000019 \\
\hline 01LRB10 & CIG1251 & 54.7 & 464 & 0.3413 & 0.0068 & 0.70719 & 0.00002 \\
\hline 01LRB16 & CIG 1252 & 64.6 & 306.6 & 0.6101 & 0.0122 & 0.709615 & 0.000021 \\
\hline 01LRB21 & CIG1253 & 52.3 & 415.5 & 0.3644 & 0.0073 & 0.707392 & 0.000023 \\
\hline Biotite & CIG 1268 & 313.07 & 19.49 & 47.64 & 0.24 & 0.959464 & 0.000294 \\
\hline
\end{tabular}

Fig. $10 \mathrm{Rb}-\mathrm{Sr}$ isochronic diagram using whole rock samples and biotite

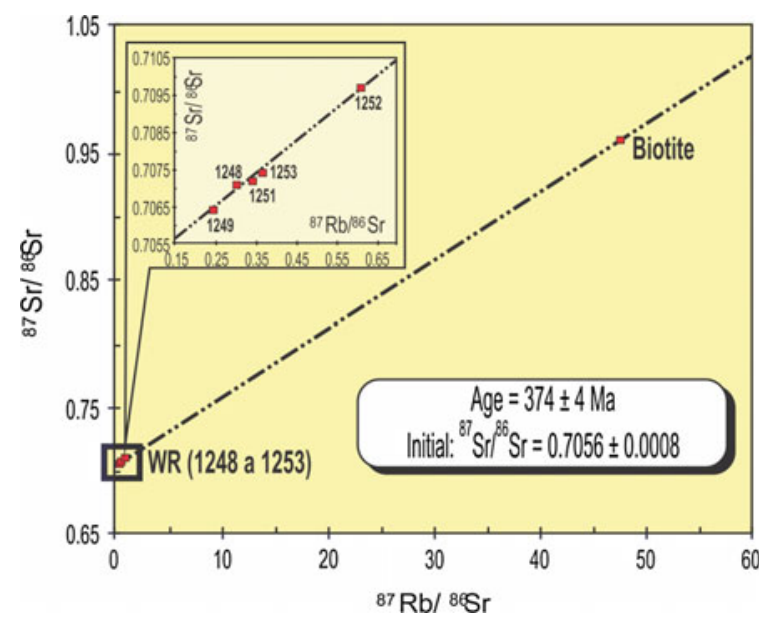

La Plata. As it is shown in Table 4, the samples show low Rb (40-60 ppm) and high $\mathrm{Sr}$ contents (300-500 ppm), with a low $\mathrm{Rb} / \mathrm{Sr}$ ratio $(0.10-0.20)$. $\mathrm{Rb}-\mathrm{Sr}$ whole rock diagram (Fig. 10) shows an alignment of five samples within a very low range of ${ }^{87} \mathrm{Rb} /{ }^{86} \mathrm{Sr}(0.24-0.61)$, and defines an 'age' of $600 \pm 100 \mathrm{Ma}$ with an IR: 0.7043 . Because the error is too high we utilized a biotite separation as Rb-rich mineral. For the biotite sample the $\mathrm{Rb} / \mathrm{Sr}$ ratio is 26 . The age obtained with the five whole rocks and the biotite is $374 \pm 4 \mathrm{Ma}$, with an IR: $0.7056 \pm 0.0006$ as we can see on the diagram from Fig. 10.

d. Sm-Nd: To apply the $\mathrm{Sm}-\mathrm{Nd}$ method, five whole rock tonalitic samples (RB1-RB 5) were used (Table 5). The isotope dilution technique for $\mathrm{Sm}-\mathrm{Nd}$ analyses (using a combined ${ }^{149} \mathrm{Sm}-{ }^{150} \mathrm{Nd}$ spike) as well as the mass spectrometry for $\mathrm{Sm}$ and $\mathrm{Nd}$ were carried out at the Laboratorio de Geología Isotópica, Universidade Federal do Rio Grande do Sul, Porto Alegre (Brazil). The isotopic ratios were measured using the VG 354 mass spectrometer with multiple collector system. The samples do not define an acceptable alignment. The model ages $\left(\mathrm{T}_{\mathrm{DM}}\right)$ calculated according to DePaolo (1981) for the whole rock samples are in the range of 1 and $1.6 \mathrm{Ga}$. The $\varepsilon_{\mathrm{Nd}}(400 \mathrm{Ma})$ for these samples is in between -4.45 and -10.20 , indicating crustal source (Fig. 11). 
Table $5 \mathrm{Sm}-\mathrm{Nd}$ analytical data

\begin{tabular}{l|l|l|l|l|r|r|l|r|l}
\hline $\begin{array}{l}\text { Field } \\
\text { No. }\end{array}$ & Sm & Nd & ${ }^{147} \mathrm{Sm} /{ }^{144} \mathrm{Nd}$ & ${ }^{147} \mathrm{Nd} /{ }^{144} \mathrm{Nd}$ & Error & $\varepsilon_{\mathrm{Nd}}(0)$ & Age & $\varepsilon_{\mathrm{Nd}}(\mathrm{t})$ & $\mathrm{T}_{\mathrm{DM}}(\mathrm{Ga})$ \\
\hline RB-1 & 4.02 & 18.66 & 0.130219 & 0.512406 & 10 & -4.52 & 400 & -0.70 & 1.2 \\
\hline RB-2 & 2.93 & 15.06 & 0.117629 & 0.512410 & 25 & -4.45 & 400 & 0.10 & 1.0 \\
\hline RB-3 & 3.79 & 19.15 & 0.119617 & 0.512354 & 15 & -5.55 & 400 & -1.12 & 1.1 \\
\hline RB-4 & 3.88 & 18.92 & 0.124118 & 0.512115 & 240 & -10.20 & 400 & -6.04 & 1.6 \\
\hline RB-5 & 3.78 & 18.78 & 0.121827 & 0.512381 & 20 & -5.02 & 400 & -0.72 & 1.1 \\
\hline
\end{tabular}

Fig. 11 The $\varepsilon_{\mathrm{Nd}}$ evolution diagram of samples at $t=400 \mathrm{Ma}$

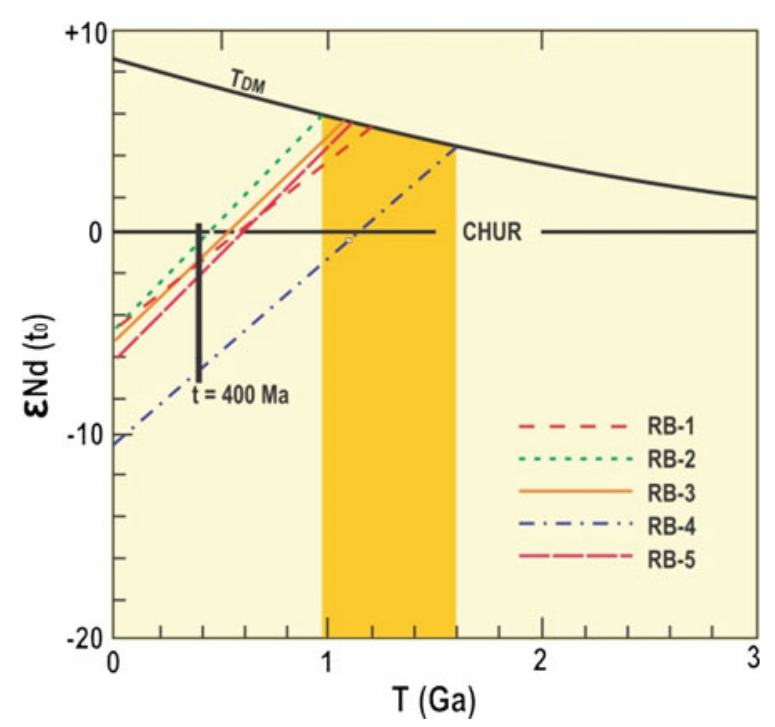

\section{Concluding Remarks}

Based on the newly obtained data the following statements can be made:

- The Rodeo de la Bordalesa tonalite dykes at San Rafael Block are characterized by high to medium potassium contents, with a metaluminous character and I-type calc-alkaline signature. It forms part of a magmatism that could be related to a post-collisional tectonic event.

- We interpret the $c a$. $400 \mathrm{Ma} \mathrm{U}-\mathrm{Pb}$ zircon age obtained within a concordia diagram, as the crystallization age which corresponds to the emplacement time. This data are confirmed by the $\mathrm{K}$-Ar biotite age. The Ordovician $\mathrm{K}$-Ar ages (González 1971) are not supported by our geochronological data and are also not consistent with the RSC paleontological record (Cingolani et al. this volume). 
- The $\mathrm{Rb}-\mathrm{Sr}$ whole rocks and biotite age of $374 \pm 4 \mathrm{Ma}$, could be linked to the 'Chanic' tectonic phase, in agreement with other geochronological data (Toubes and Spikermann 1976, 1979). Cingolani and Varela (2008) presented a Rb-Sr isochronic whole rock age of $336 \pm 23 \mathrm{Ma}$ for the anchimetamorfic event that affected the Río Seco de los Castaños unit, implying an Early Carboniferous (Mississipian) low-grade metamorphism for the RSC. Tickyj et al. (2001), based on similar isotopic studies determined isochronic whole rock ages ranging from $371 \pm 62$ to $379 \pm 15 \mathrm{Ma}$ for the La Horqueta sequence, from which suggested an Upper Devonian low-grade metamorphism. Similar data were obtained in metasedimentary rocks from Precordillera (Cucchi 1971; Buggish et al. 1994; Ramos et al. 1998; Davis et al. 1999) that strongly suggests Upper Devonian-Lower Carboniferous age for the synmetamorphic ductile deformation in the western side of Cuyania terrane in connection with the 'Chanic' tectonic phase.

- Nd model ages $\left(\mathrm{T}_{\mathrm{DM}}\right)$ show an interval between 1 and $1.6 \mathrm{Ga}$ that corresponds to Mesoproterozoic age derivation and the negative $\varepsilon_{\mathrm{Nd}}$ is in accordance to crustal sources.

- The crystallization age for the Rodeo de la Bordalesa tonalite dykes corresponds to a Lower Devonian time (Pragian-Emsian boundary) according to IUGS time scale and suggests that part of the Late Famatinian magmatic event is present in the San Rafael Block. The tonalite rocks are contemporaneous with the large peraluminous batholith exposed in Pampean Ranges (Rapela et al. 1992; Dahlquist et al. 2014), with the transpressional shear belts during 'Achalian' event (Sims et al. 1998); it could be as well correlated with the Devonian magmatism present in Pampa de los Avestruces (Tickyj et al. 2009) in the southern part of the Frontal Cordillera and some places studied recently by Tickyj et al. (2015) near Agua Escondida Mine District in the southern sector of the SRB.

- The geochemical and geochronological data allow us to differentiate the Rodeo de la Bordalesa tonalite from the mafic rocks (mainly porphyritic dolerites with tholeiitic signature) exposed at the El Nihuil area.

Acknowledgements Field and laboratory work was financed by PIP-CONICET grants 647 and 199. We thank Ricardo Varela for Rb-Sr whole rock laboratory preparation. Diego Licitra, Leonardo Ortiz and Natalia Hernández helped us in field work, mineralogical separation, and petrographical descriptions. We acknowledge to Mario Campaña for technical assistance. To Alejandro Capelli for kind permission to access at the outcrops near the deactivated railroad tracks ('Ferrocarril General San Martin'). Domingo Solorza from Puesto Cortaderas, helped us in a field work activities.

\section{References}

Bellieni G, Visentin J, Zanettin B (1995) Use of the chemical TAS diagram (total alkali-silica) for classification of plutonic rocks: problems and suggestions. PLINIUS (Supplemento italiano all'Eur J Miner) 14:49-52

Buggish W, von Gosen W, Henjes-Kunst E, Krumm S (1994) The age of early Paleozoic deformation and metamorphism in the Argentine Precordillera-Evidence from K-Ar data. Zentralbl Geol Palaontol Teil I:275-286 
Cingolani CA, Llambías EJ, Ortiz LR (2000) Magmatismo básico pre-Carbónico del Nihuil, Bloque de San Rafael, Provincia de Mendoza, Argentina. In: $9^{\circ}$ Congreso Geológico Chileno, vol 2. Puerto Varas, pp 717-721

Cingolani CA, Basei MAS, Llambías EJ, Varela R, Chemale Jr F, Siga O Jr, Abre P (2003) The Rodeo Bordalesa Tonalite, San Rafael Block (Argentina): Geochemical and isotopic age constrains. In: $10^{\circ}$ Congreso Geológico Chileno, Concepción, p 10 (CD Rom)

Cingolani CA, Varela R (2008) The Rb-Sr low-grade metamorphism age of the Paleozoic Río Seco de los Castaños Formation, San Rafael Block, Mendoza, Argentina. VII South American symposium on Isotope Geology, S.C. Bariloche, Argentina, p 4 (CD-ROM)

Cingolani CA, Varela R, Chemale Jr F, Uriz NJ (2011) Geocronología U-Pb de las monzodioritas de la Boca del Río, Cacheuta-Mendoza, Argentina. In: $18^{\circ}$ Congreso Geológico Argentino, Simposio de Tectónica pre-Andina. Actas. Neuquén, p 2 (CD Rom)

Cingolani CA, Uriz NJ, Abre P, Manassero MJ, Basei MAS (this volume) Silurian-Devonian land-sea interaction within the San Rafael Block, Argentina: Provenance of the Rio Seco de los Castaños Formation. In: Cingolani C (ed) Pre-Carboniferous evolution of the San Rafael Block, Argentina. Implications in the SW Gondwana margin. Springer (Chapter 10)

Criado Roqué P, Ibáñez G (1979) Provincia geológica Sanrafaelino-Pampeana. In: Turner JCM (ed) Geología Regional Argentina. Academia Nacional de Ciencias, I, pp 745-769

Cucchi RJ (1971) Edades radimétricas y correlación de metamorfitas de la Precordillera, San Juan-Mendoza, Rep. Argentina. Rev Asoc Geol Argent 28(3):241-267

Cuerda AJ, Cingolani CA (1998) El Ordovícico de la región del cerro Bola en el Bloque de San Rafael, Mendoza: sus faunas graptolíticas. Ameghiniana 35(4):427-448. Buenos Aires

Dahlquist JA, Alasino PH, Bello C (2014) Devonian F-rich peraluminous A-type magmatism in the proto-Andean foreland (Sierras Pampeanas, Argentina): geochemical constraints and petrogenesis from the western central region of the Achala batholiths. Mineral Petrol 108:391417

Davicino RE, Sabalúa JC (1990) El cuerpo básico de El Nihuil, Depto. San Rafael, Pcia. de Mendoza, Rep. Argentina. In: $11^{\circ}$ Congreso Geológico Argentino, San Juan, Actas, vol 1, pp $43-47$

Davis J, Roeske S, McClelland W, Snee L (1999) Closing the ocean between the Precordillera terrane and Chilenia: early Devonian ophiolite emplacement and deformation in the Southwest Precordillera. In: Ramos VA, Keppie, JD (eds) Laurentia-Gondwana connections before Pangea. Geological Society of America, Special Paper 336. Boulder, Co. USA, pp 115-138

DePaolo DJ (1981) Neodymiun isotopes in the Colorado Front Range and implications for crust formation and mantle evolution in the Proterozoic. Nature 291:193-197

Dessanti RN (1956) Descripción geológica de la Hoja 27c-cerro Diamante (Provincia de Mendoza). Dirección Nacional de Geología y Minería. Boletín, vol 85. Buenos Aires, p 79

Di Persia CA (1972). Breve nota sobre la edad de la denominada Serie de la Horqueta- Zona Sierra Pintada. Departamento de San Rafael, Provincia de Mendoza. 4a Jornadas Geológicas Argentinas, vol 3. Mendoza, pp 29-41

González RN (1971) Edades radimétricas de algunos cuerpos eruptivos de Argentina. Rev Asoc Geol Argent 26(3):411-412

González Díaz EF (1964) Rasgos geológicos y evolución geomorfológica de la Hoja 27 d, San Rafael y su zona vecina occidental (Pcia. de Mendoza). Asoc Geol Argent Rev XIX(3):151188

González Díaz EF (1981) Nuevos argumentos a favor del desdoblamiento de la denominada "Serie de la Horqueta" del Bloque de San Rafael, Provincia de Mendoza. In: $8^{\circ}$ Congreso Geológico Argentino, Actas, vol 3. San Luis, pp 241-256

Harris NBW, Pearce JA, Tindle AG (1986) Geochemical characteristics of collision-zone magmatism. In: Coward MP, Rios AC (eds) Collision tectonics. Geological Society of London, Special Bulletin, vol 19, pp 67-81

Irvine TN, Baragar WRA (1971) A guide to the chemical classification of the common rocks. Can J Earth Sci 8:523-548 
IUGS (2015) International Chronostratigraphic Chart. International Commission on Stratigraphy, International Union of Geological Sciences (IUGS)

Linares E, Parica C, Parica P (1987) Catálogo de edades radimétricas determinadas para la República Argentina (IV años 1979-1980 realizadas por INGEIS y sin publicar y V años 1981-1982 publicadas). Publicaciones Especiales, Asociación Geológica Argentina, Serie B (Didáctica y Complementaria), vol 15, pp 1-49

Ludwig KR (1999) Using Isoplot/Ex, version 2. A geochronological toolkit for Microsoft excel. Berkeley Geochronological Center, Special Publication 1a, $47 \mathrm{p}$

Ludwig KR (2001) Squid 1.02: a user manual. Berkeley Geochronl Cent Spec Publ 2:19

Manassero MJ, Cingolani CA, Abre P (2009) A Silurian-Devonian marine platform-deltaic system in the San Rafael Block, Argentine Precordillera-Cuyania terrane: lithofacies and provenance. In: Konigshof P (ed). Devonian change: case studies in Palaeogeography and Palaeoecology. The Geological Society, vol. 314. Special Publications, London, pp 215-240

Maniar PD, Piccoli PM (1989) Tectonic discrimination of granitoids. Geol Soc Am Bull 101:635643

Pazos PJ, Heredia AM, Fernández DE, Gutiérrez C, Comerio M (2015) The ichnogenus Dictyodora from late Silurian deposits of central-western Argentina: Ichnotaxonomy, ethology and ichnostratigrapical perspectives from Gondwana. Palaeogeogr Palaeoclimatol Palaeoecol 439:27-37. doi:10.1016/j.palaeo.2015.02.008

Pearce JA, Harris NBW, Tindle AG (1984) Trace element discrimination diagrams for the tectonic interpretation of granitic rocks. J Petrol 25:956-983

Peccerillo A, Taylor SR (1976) Geochemistry of Eocene calc-alkaline volcanic rocks from the Kastamonu area, northern Turkey. Contrib Miner Petrol 58:63-81

Poiré DG, Cingolani C, Morel E (1998) Trazas fósiles de la Formación Horqueta (Silúrico), Bloque de San Rafael, Mendoza, Argentina. Tercera Reunión de Icnología y Primera Reunión de Icnología del Mercosur, Resúmenes, vol 24. Mar del Plata

Ramos VA (2004) Cuyania, an exotic block to Gondwana: review of a historical success and the present problems. Gondwana Res 7:1009-1026

Ramos VA, Dallmeyer R, Vujovich GI (1998) Time constrains on the early Paleozoic docking of the Precordillera central Argentina. In: Pankhurst RJ, Rapela CW (eds) The Proto-Andean Margin of Gondwana. Geological Society of London, Special Publication, vol 142, pp 143158

Rapela CW, Coira B, Toselli A, Saavedra J (1992) The lower Paleozoic magmatism of south-western Gondwana and the evolution of the Famatinian orogen. Int Geol Rev 34:10811142

Rubinstein C (1997) Primer registro de palinomorfos silúricos en la Formación La Horqueta, Bloque de San Rafael, provincia de Mendoza, Argentina. Ameghiniana 34(2):163-167

Sims JP, Ireland TR, Camacho A, Lyons P, Pieters PE, Skirrow RG, Stuart-Smith PG (1998) U$\mathrm{Pb}, \mathrm{Th}-\mathrm{Pb}$ and $\mathrm{Ar}-\mathrm{Ar}$ geochronology from the southern Sierras Pampeanas, Argentina: implications for the Palaeozoic tectonic evolution of the western Gondwana margin, In: Pankhurst RJ, Rapela CW (eds) The Proto-Andean margin of Gondwana. Geological Society of London, Special Publication, vol 142, pp 259-282

Steiger RH, Jager E (1977) Subcommission on geochronology: convention on the use of decay constants in geochronology and cosmochronology. Contribution to the geologic time scale, AAPG, Studies in Geology 6:67-71

Taylor SR, McLennan SM (1985) The continental crust: its composition and evolution. Blackwell, Oxford, $312 \mathrm{p}$

Tickyj H, Cingolani CA, Chemale Jr F (2001) Rb-Sr ages from La Horqueta Formation, San Rafael Block (Argentina). In: III South American symposium on isotope geology, Pucón, Chile (CD Rom)

Tickyj H, Fernández MA, Chemale Jr F, Cingolani C (2009) Granodiorita Pampa de los Avestruces, Cordillera Frontal, Mendoza: un intrusivo sintectónico de edad devónica inferior. In: $14^{\circ}$ Reunión de Tectónica. Libro de resúmenes, vol 27, Río Cuarto, Argentina 
Tickyj H, Tomezzoli MA, Basei MAS, Fernández MA, Blatter JM, Rodríguez N, Gallo LC (2015) Geología de la Formación Piedra de Afilar, basamento granítico del Distrito Minero Agua Escondida, Mendoza. In: $3^{\circ}$ Simposio sobre Petrología Ígnea y Metalogénesis Asociada. Río Negro, Argentina

Toubes RO, Spikermann JP (1976) Algunas edades K-Ar para la Sierra Pintada, provincia de Mendoza. Rev Asoc Geol Argent 31(2):118-126

Toubes RO, Spikermann JP (1979) Nuevas edades K-Ar para la Sierra Pintada, provincia de Mendoza. Rev Asoc Geol Argent 34(1):73-79

Whalen JB, Currie KL, Chappel BW (1987) A-type granites: geochemical characteristics, discrimination and petrogenesis. Contrib Miner Petrol 95:407-419 